\section{The "Index Kewensis."}

Index Kexvensis Plantarum Phanerogamarum. Supplementum Quintum Nomina et Synonyma Omnium Generum et Specierum ab Initio Anni MDCCCCXI usque ad finem Anni MDCCCCXV Nonnulla Etiam Antea Edita Complectens. Ductu et Consilio D. Prain, confecerunt Herbarii Horti Regii Botanici Kewensis Curatores. Pp. iii +277 . (Oxonii : e Prelo Clarendoniano, 1921.) 76s. net.

$\mathrm{T}$ HERE is probably no publication which is awaited with such interest and impatience as the issue from time to time of the supplements of the "Index Kewensis." Had it not been for the interruption of the war, the list of genera and species published, or the publication of which was ascertained, in the five years I9II-I5, would doubtless have been available to botanists less than six years after the second date. This delay was inevitable, but it may be assumed that Supplement 6, comprising the years $1916-20$, is well on the way and will be available for workers before another five years have passed. Some names published abroad during I9r4 and Igr5 were not noted in time for insertion in the present supplement, but will be included in the next.

A rough estimate shows that the present volume indexes more than 33,000 species-names, and a perusal of a few columns indicates the large number and great variety of the books and periodicals which have been searched during the compilation of the work, which, so far as one can judge by inspection and trial, maintains the high standard of accuracy and completemess of the parts previously issued. It is a great help to have a note of the date of publication of the book or periodical cited; the absence of this was a disadvantage in the earlier volumes. Similarly the practice adopted in the previous supplement of not attempting to distinguish between species and synonyms, often a matter of personal opinion, has again been followed, and the work maintains its character purely of an index. Attention is directed in the preface to the fuller geographical citations as compared with previous volumes; thus in American species the name of the State follows the indication U.S.A. ; in Chinese, the name of the province, and so on; this additional information is a distinct gain.

To the botanist a perusal of the columns is of special interest as marking the progress of botanical exploration generally; thus the large number of genera and species quoted as from China, especially the southwestern provinces and the Philippine Islands, suggests the important work being carried on in those areas by British and American collectors and investigators. The progress of standard floristic works, such as the
"Flora of Tropical Africa," or series of monographs, such as the "Pflanzenreich,". is also recorded in these cases under the genera of families specially concerned.

The numerous entries under certain well-known European genera, such as Hieracium, which fills ten pages, and Rubus, which fills eight, recall the intensive study of species and their segregation, which will doubtless continue to supply material for future supplements. The many unwieldy trivial names, sometimes running into eight syllables, indicate the difficulty of finding new names for species when these run into the hundreds in individual genera. The occasional appearance of names from periodicals antedating the special period shows the great difficulty of sweeping up all the literature. Thus a harvest of new names has been supplied by Hegetschweiler's "Flora der Schweiz" (I839), previously overlooked, and the recognition of Philip Miller's "Abridged Dictionary of Gardening " (edition of $17 \dot{5} 4$ ), in which many genera were carefully defined, necessitates the reference of some well-known genera to Miller instead of to later authorities.

In the method of citation the recommendation of the latest International Code of Rules is followed in the use of the capital letter only for species-names derived from a personal or a generic name. In the manner of production, from the irreproachable Latin preface onwards, the volume upholds the credit of the Oxford University Press.

\section{Mental Measurement.}

(1) The Essentials of Mental Measurement. By Dr. W. Brown and Prof. G. H. Thomson. (The Cambridge Psychological Library.) Pp. $\mathrm{x}+2 \mathrm{r} 6$. (Cambridge: At the University Press, 192r.) 2Is. net.

(2) How to Meusure. By Prof. G. M. Wilson and Prof. K. J. Hoke. Pp. vii +285 . (New York: The Macmillan Company; London: Macmillan and Co., Ltd., I920.) I2s. net.

(r) FLEVEN years ago Dr. William Brown E published as a thesis for his doctorate a suggestive and original monograph on the use of the theory of correlation in psychology. Later, by adding one or two chapters of introduction and two or three others on the so-called psychophysical methods, he expanded this monograph into a compact manual entitled "The Essentials of Mental Measurement." Now, in turn, after another and a longer interval, the manual itself has developed into a guinea royal-octavo volume, extensively enlarged and exhaustively revised.

The larger additions consist for the most part of a detailed series of mathematical arguments, examining what is termed the " hierarchical theory," and bringing

$$
\text { NO. } 2737 \text {, VOL. IO9] }
$$

